\title{
MDRD Enzymatic Japanese Formula
}

National Cancer Institute

\section{Source}

National Cancer Institute. MDRD Enzymatic Japanese Formula. NCI Thesaurus. Code C161347.

A formula to estimate glomerular filtration rate in Japanese subjects that takes into account age, sex, and serum creatinine. eGFR $(\mathrm{ml} / \mathrm{min} / 1.73 \mathrm{~m} 2)=194 \times$ PD93 power^_ 1.094 x Age power^- 0.287 x Sex; where PD93 = Serum $\mathrm{Cr}(\mathrm{mg} / \mathrm{dL})$, Sex = 1.00 for male and 0.739 for female. (Imai E, Horio M, Nitta K, Yamag ata K, Iseki K, T sukamoto Y, Ito S, Makino H, Hishida A, Matsuo S. Modification of the Modification of Diet in Renal Disease (MDRD) Study equation for Japan. Am J Kidney Dis. 2007 Dec;50(6):927-37.) 